\title{
THE STRUCTURES OF ORYZOXYMYCIN AND ITS DIMERIZATION PRODUCT
}

\author{
Toshihrro Hashimoto, Shujt Takahashi, Hiroshi Naganawa, \\ Tomohisa Takita, Kenji Maeda and Hamao Umezawa \\ Institute of Microbial Chemistry, \\ Kamiosaki, Shinagawa-ku, Tokyo, Japan \\ (Received for publication April 25, 1972)
}

Oryzoxymycin (I), an antibiotic produced by Streptomyces venezuelae var. oryzoxymyceticus, is unstable and easily dimerizes to an inactive crystalline product. Structural study of this product led to the conclusion that the structure of oryzoxymycin is $\mathrm{D}-2-[(+)-6$-amino-trans-5-hydroxy-1,3-cyclohexadiene1-carbonyloxy]-propionic acid:

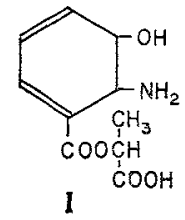

Oryzoxymycin (I) ${ }^{1)}$ is an antibiotic isolated from a cultured broth of Streptomyces venezuelae var. oryzoxymyceticus. It inhibits growth of Xanthomonas oryzae at 1.56 $\mathrm{mcg} / \mathrm{ml}$ on glucose nutrient agar, but it does not show preventive or curative effect against infection of $X$. oryzae even at $1,000 \mathrm{mcg} / \mathrm{ml}$ in the pot test. One of the reasons of the ineffectiveness in the pot test seems to be due to the rapid dimerization of this antibiotic.

Oryzoxymycin (I) is obtained as amorphous powder, $\mathrm{mp} 155^{\circ} \mathrm{C}$ (dec.), $\lambda_{\max }$ at $284 \mathrm{~nm}, \nu_{c=0}$ at $1725 \mathrm{~cm}^{-1}$ (ester), pKá 2.7 and 8.1. It is very unstable, losing the activity and yielding the crystalline dimerization product. Oryzoxymycin absorbs two moles of hydrogen on catalytic hydrogenation and gives tetrahydro-oryzoxymycin [colorless needles, $\mathrm{mp} 213 \sim 215^{\circ} \mathrm{C}$ (dec.), $\nu_{\mathrm{c}=0}$ at $1724 \mathrm{~cm}^{-1}$ (ester)] which has no uv maximum and has the molecular formula $\mathrm{G}_{10} \mathrm{H}_{17} \mathrm{NO}_{5}$ determined by the elemental analysis and the mass spectrometry $\left(\mathrm{M}^{+} 231\right)$. Therefore, the molecular formula of oryzoxymycin which was reported in a previous paper ${ }^{1)}$ should be revised to $\mathrm{C}_{10} \mathrm{H}_{13} \mathrm{NO}_{5}$. At first, we studied the structure of the stable crystalline dimerization product and the result led to the structure of oryzoxymycin (I), D-2-[(+)-6-amino-trans-5-hydroxy1,3-cyclohexadiene-1-carbonyloxy]-propionic acid. Hydrolysis of I with $2 \mathrm{~N} \mathrm{NaOH}$ at $60^{\circ} \mathrm{C}$ for 5 hours gives D-lactic acid and (+)-6-amino-trans-5-hydroxy-1,3-cyclohexadiene-1-carboxylic acid which was isolated by McCormick et al. ${ }^{2)}$ from Streptomyces aureofaciens.

Oryzoxymycin, kept at room temperature in a dry state, gradually loses its 
activity and yields a crystalline substance (II), $m p$ 185- $193^{\circ} \mathrm{C}$ (dec.). The latter has no uv maximum, and ir spectrum of II indicates the presence of ester functions $\left(1747 \mathrm{~cm}^{-1}\right)$. The molecular formula $\mathrm{C}_{20} \mathrm{H}_{26} \mathrm{~N}_{2} \mathrm{O}_{10}$ is calculated from the results of the elemental analysis and the titration equivalent. Alkaline hydrolysis of II gives two crystalline products, (III) and (IV), and III still keeps an ester function $\left(1742 \mathrm{~cm}^{-1}\right)$, but IV does not. Compound IV is also obtained by further alkaline hydrolysis of III. The molecular formulae $\mathrm{C}_{17} \mathrm{H}_{22} \mathrm{~N}_{2} \mathrm{O}_{8}$ and $\mathrm{C}_{14} \mathrm{H}_{18} \mathrm{~N}_{2} \mathrm{O}_{6}$ are obtained from their elemental analysis, respectively.

These observations indicate that III is II minus a $\mathrm{C}_{s}$ fragment, and IV is III minus the same $\mathrm{C}_{3}$ fragment. The $\mathrm{C}_{3}$ fragment was isolated from effluent of cation-exchange resin chromatography of the alkaline hydrolyzate and identified to be D-lactic acid by comparison with an authentic sample.

The nmr spectrum reveals that two hydroxyl groups of two lactic acids form esters in II, that is, protons on $\alpha$-carbons of two lactic acid moieties appear at $5.20 \delta$ and $5.30 \delta$, while the proton of free lactic acid is at $4.20 \delta$.

Compound IV has two each of pri-

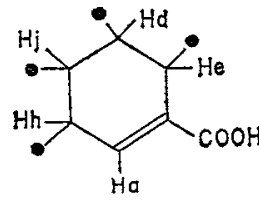

A

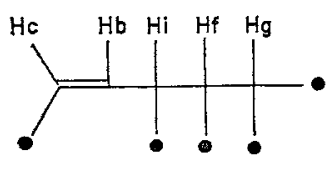

B
Table 1. Chemical shifts and coupling constants of protons of IV $(100 \mathrm{M} \mathrm{Hz})$

\begin{tabular}{l|l|l}
\multicolumn{3}{|c}{ of protons of IV $(100 \mathrm{M} \mathrm{Hz})$} \\
\hline Proton & $\begin{array}{c}\text { Chemical } \\
\text { shift }\end{array}$ & \multicolumn{1}{|c}{ Coupling constant } \\
\hline $\mathrm{Ha}$ & $7.01(\delta)$ & $\mathrm{Jah}=3.5 \mathrm{Jae}=2.2$ \\
$\mathrm{Hb}$ & 6.49 & $\mathrm{Jbc}=9.0 \mathrm{Jbi}=7.0$ \\
$\mathrm{Hc}$ & 6.31 & $\mathrm{Jcb}=9.0 \mathrm{Jcg}=0.5 \mathrm{Jch}=0.5$ \\
$\mathrm{Hd}$ & 4.12 & $\mathrm{Jde}=9.5 \mathrm{Jdj}=6.3$ \\
$\mathrm{He}$ & 3.76 & $\mathrm{Jed}=9.5 \mathrm{Jeh}=2.5 \mathrm{Jea}=2.2$ \\
$\mathrm{Hf}$ & 3.63 & $\mathrm{Jfg}=4.2 \mathrm{Jfi}=3.0$ \\
$\mathrm{Hg}$ & 3.51 & $\mathrm{Jgf}=4.2 \mathrm{Jgc}=0.5$ \\
$\mathrm{Hh}$ & 3.15 & $\mathrm{Jhj}=9.0 \mathrm{Jha}=3.5 \mathrm{Jhe}=2.5 \mathrm{Jhc}=0.5$ \\
$\mathrm{Hi}$ & 3.09 & $\mathrm{Jib}=7.0 \mathrm{Jif}=3.0$ \\
$\mathrm{Hj}$ & 3.05 & $\mathrm{Jjh}=9.0 \mathrm{Jjd}=6.3$ \\
\hline
\end{tabular}

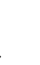

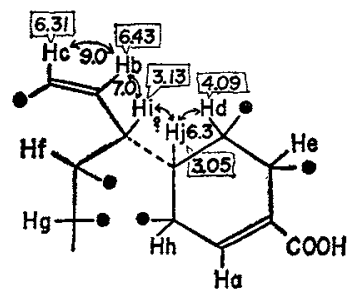

Partial structure $C$ of $N$

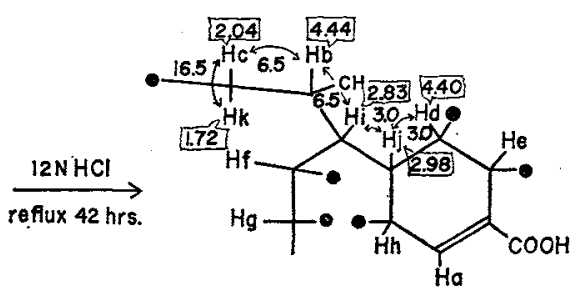

Partial structure of $V$

Table 2. Chemical shifts and coupling constants of protons of $\mathrm{V}(100 \mathrm{M} \mathrm{Hz})$

\begin{tabular}{c|l|lll}
\hline Proton & $\begin{array}{c}\text { Chemical } \\
\text { shift }\end{array}$ & \multicolumn{3}{|c}{ Coupling constant } \\
\hline $\mathrm{Ha}$ & $7.18(\delta)$ & $\mathrm{Jah}=4.0$ & & \\
$\mathrm{Hb}$ & 4.44 & $\mathrm{Jbi}=6.0$ & $\mathrm{Jbc}=6.0$ & $\mathrm{Jbk}=<1$ \\
$\mathrm{Hc}$ & 2.04 & $\mathrm{Jcb}=6.2$ & $\mathrm{Jch}=2.0$ & \\
$\mathrm{Hd}$ & 4.40 & $\mathrm{Jdj}=2.0$ & $\mathrm{Jde}=0$ & \\
$\mathrm{He}$ & 4.18 & $\mathrm{Jed}=0$ & & \\
$\mathrm{Hf}$ & 3.71 & $\mathrm{Jfi}=2.8$ & $\mathrm{Jfg}=5.0$ & \\
$\mathrm{Hg}$ & 3.26 & $\mathrm{Jgf}=5.0$ & $\mathrm{Jgk}=1.5$ & \\
$\mathrm{Hh}$ & 2.99 & $\mathrm{Jhc}=2.0$ & $\mathrm{Jha}=4.0$ & $\mathrm{Jhj}=9.5$ \\
$\mathrm{Hi}$ & 2.83 & $\mathrm{Jib}=6.0$ & $\mathrm{Jif}=2.8$ & $\mathrm{Jij}=3.0$ \\
$\mathrm{Hj}$ & 2.98 & $\mathrm{Jjd}=2.0$ & $\mathrm{Jjh}=9.5$ & $\mathrm{Jji}=3.0$ \\
$\mathrm{Hk}$ & 1.72 & $\mathrm{Jkb}=<1$ & $\mathrm{Jkg}=1.5$ & \\
\hline
\end{tabular}

mary amino (VAN SLYKE method), carboxyl (formation of dimethyl ester), and hydroxyl groups (formation of tetraacetyl derivative). These functional groups account for all the nitrogen and oxygen present in IV. Compound IV absorbs two moles of hydrogen on catalytic hydrogenation.

The nmr spectrum of IV (Table 1) taken in deuterated dilute hydrochloric acid solution was analyzed with the aid 
Table 3. Chemical shifts of Hd, He, Hf and

\begin{tabular}{c|c|c|c|c|c}
\multicolumn{6}{c}{$\mathrm{Hg}$ of IV and the derivative } \\
\hline Proton & $\begin{array}{c}\text { a) Hydro- } \\
\text { chloride } \\
\left(\mathrm{D}_{2} \mathrm{O}\right)\end{array}$ & $\begin{array}{c}\text { b) Free } \\
\text { base } \\
\left(\mathrm{D}_{2} \mathrm{O}\right)\end{array}$ & $\begin{array}{c}\text { c) Tetra- } \\
\text { acetyldime- } \\
\text { thyl ester } \\
\left(\mathrm{CDCl}_{3}\right)\end{array}$ & $(\mathrm{a}-\mathrm{b})$ & $(\mathrm{c}-\mathrm{b})$ \\
\hline $\mathrm{Hc}$ & 6.31 & 6.31 & 6.41 & 0 & 0.10 \\
$\mathrm{Hd}$ & 4.12 & 3.85 & 5.18 & 0.27 & 1.30 \\
$\mathrm{He}$ & 3.76 & 3.30 & 4.63 & 0.46 & 1.33 \\
$\mathrm{Hf}$ & 3.63 & 3.40 & 4.30 & 0.23 & 0.90 \\
$\mathrm{Hg}$ & 3.51 & 2.90 & 4.30 & 0.61 & 1.40 \\
$\mathrm{Hh}$ & 3.15 & 3.10 & $?$ & 0.05 & $?$ \\
\hline
\end{tabular}

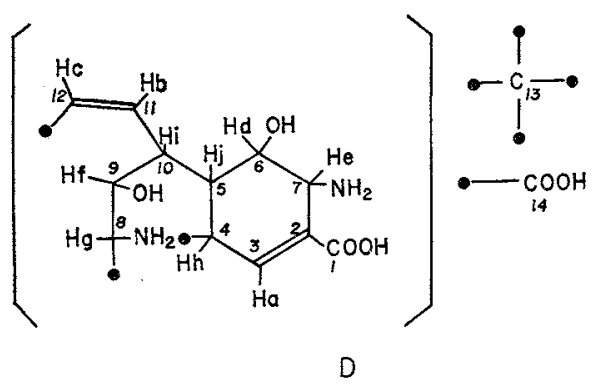

of double resonance technique. Then the results indicated the partial structures $A$ and $\mathrm{B}$.

Partial structures A and B account for all the protons presentin the nmr spectrum and twelve carbons of IV. One of the remaining two carbons should be a carboxyl carbon and the other could be considered to be a quaternary carbon. Concerning the linkage of partial structures $A$ and $B$, the $n m r$ spectrum of IV did not give definite information. The nature of the linkage (as shown by the partial structure $\mathrm{C}$ for IV and the partial structure V) was solved by $\mathrm{nmr}$ analysis (Table 2) of a hydrated product of IV (V), $\left(\mathrm{C}_{14} \mathrm{H}_{20} \mathrm{~N}_{2} \mathrm{O}_{7}, \mathrm{mp}>260^{\circ} \mathrm{C}\right)$, which was obtained by refluxing IV in $12 \mathrm{~N} \mathrm{HGl}$ for 42 hours.

Chemical shifts of $\mathrm{Hc}, \mathrm{Hd}, \mathrm{He}, \mathrm{Hf}, \mathrm{Hg}$ and $\mathrm{Hh}$ of IV and its tetraacetyl dimethyl ester are shown in Table 3. These data indicate that hydroxyl groups of IV are present at $\mathrm{C}-6(\mathrm{Hd})$ and $\mathrm{C}-9(\mathrm{Hf})$, and amino groups at $\mathrm{C}-7(\mathrm{He})$ and $\mathrm{C}-8(\mathrm{Hg})$, and lead to the partial structures $D$ of IV.

From the partial structure D, the structure IV can be directly constructed and structures II, III and V can be proposed as follows:

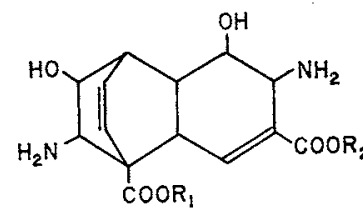

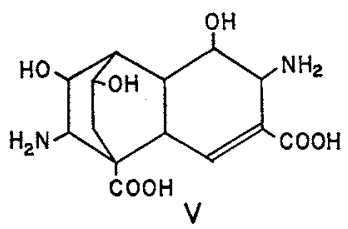<smiles>[R7]CC([R17])C(=O)OCC(C)C(=O)O</smiles>

Table 4. Chemical shifts of Ha, $\mathrm{He}, \mathrm{Hh}$ and $\mathrm{Hg}$ of compounds II, III and IV

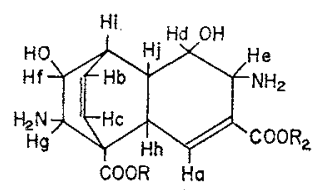

IV $R_{1}=R_{2}:-H$

\begin{tabular}{c|c|c|c|c}
\hline \multirow{2}{*}{ Compound } & \multicolumn{3}{|c}{ Chemical shift $(\delta)$} \\
\cline { 2 - 5 } & $\mathrm{Ha}$ & $\mathrm{He}$ & $\mathrm{Hh}$ & $\mathrm{Hg}$ \\
\hline II & 7.15 & 3.90 & 3.65 & 3.70 \\
III & 7.05 & 3.75 & 3.65 & 3.72 \\
IV & 7.01 & 3.76 & 3.15 & 3.51 \\
\hline
\end{tabular}

The position of the lactic ester group in III is shown by comparison of chemical shifts of neighboring protons of carbonyl functions of II, III and IV (Table 4).

The proposed structure of II indicates the following dimerization process from I : 


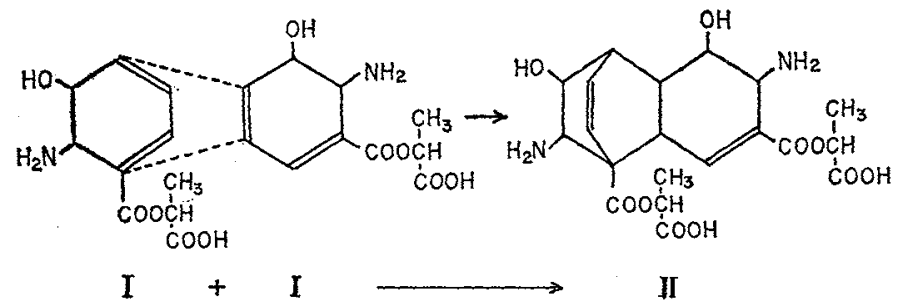

\section{Experimental}

The melting points were determined in capillary tubes and are uncorrected. The ultraviolet spectra were recorded on a Hitachi EPS-2U spectrophotometer. The infrared spectra were recorded on a Hitachi EPI-S2 spectrometer. The nuclear magnetic resonance spectra were measured on Varian A-60D and HA-100 instruments, and the internal standards used in deutrium oxide and in organic solvents were sodium 2,2-dimethyl-2silapentane-5-sulfonate (DSS) and tetramethylsilane (TMS), respectively. The mass spectra were measured on a JEOL JMS-01SG spectrometer by direct inlet method. Rotations were measured on a Carl Zeiss LEP-A2 photoelectric polarimeter. The pKá values were determined on a Metrohm Herisau E-436 potentiograph, and samples were dissolved in $0.1 \mathrm{~N} \mathrm{HCl}$ and titrated with $1 \mathrm{~N} \mathrm{NaOH}$. Silica gel "G" (Merck) was used in thin-layer chromatography and spots were detected by spraying with one of the following reagents; $0.5 \% \quad \mathrm{KMnO}_{4}$ aqueous solution, $10 \% \mathrm{H}_{2} \mathrm{SO}_{4}$ solution, and $0.2 \%$ ninhydrin in acetone solution containing $5 \%$ pyridine. For the latter two reagents, the plate was heated at $105^{\circ} \mathrm{C}$ after spraying.

Oryzoxymycin: D-2-[(+)-6-amino-trans-5-hydroxy-1,3-cyclohexadiene-1-carbonyloxy $]-$ propionic acid (I)

Compound I was obtained as colorless amorphous powder from a cultured broth of Streptomyces venezuelae var. oryzoxymyceticus as previously described ${ }^{1)}$ : $m p 155^{\circ} \mathrm{C}$ (dec.); $[\alpha]_{\mathrm{D}}^{22}+349^{\circ}$ (c 1, water); $\lambda_{\max }(\varepsilon), 284 \mathrm{~nm}(6470)$ in $0.1 \mathrm{~N} \mathrm{HCl}^{1)} ; \lambda_{\max }\left(\mathrm{KBr}\right.$ disk), $1725 \mathrm{~cm}^{-1}$ (ester). Anal. calcd. for $\mathrm{C}_{10} \mathrm{H}_{13} \mathrm{NO}_{5}$ : C 52.86, H 5.77, N 6.17, O 35.21, (M.W. 227.21). Found: C 53.02, H 5.82, N 6.30, O 35.21, M.W. 224 (titration).

Oryzoxymycin dimer (II)

Three grams of I was kept at room temperature for 3 days and dissolved in $10 \mathrm{ml}$ of water. By addition of $10 \mathrm{ml}$ of ethanol, $2.1 \mathrm{~g}$ of crystalline substance was obtained. Recrystallization from ethanol - water gave $1.75 \mathrm{~g}$ ( $58 \%$ yield) of colorless needles; mp 185 193 ${ }^{\circ} \mathrm{C}$ (dec.), $[\alpha]_{\mathrm{D}}^{22}+30^{\circ}$ (c 1, water), pKá $<2,2.5,7.2,8.6$; wv, end absorption; $\lambda_{\max }(\mathrm{KBr}$ disk), $1747 \mathrm{~cm}^{-1}$ (ester). Anal. calcd. for $\mathrm{C}_{20} \mathrm{H}_{26} \mathrm{~N}_{2} \mathrm{O}_{10} \cdot \mathrm{H}_{2} \mathrm{O}$ : C 50.84, H 5.97, N 5.93, O 37.25, (M.W. 472.46). Found: C 50.95, H 6.10, N 5.78, O 37.00, M.W. 470 (titration).

Monodeslactic oryzoxymycin dimer (III) and dideslactic oryzoxymycin dimer (IV)

A $10 \mathrm{~g}$ of II was dissolved in $150 \mathrm{ml}$ of $2 \mathrm{~N} \mathrm{NaOH}$, and was hydrolyzed at $60^{\circ} \mathrm{C}$ for 5 hours. The reaction mixture was added to a column of Dowex $50 \mathrm{~W}-\mathrm{X} 8$ (H type, $\phi=4 \mathrm{~cm}$, $500 \mathrm{ml})$. The column was washed with water, and eluted with $0.5 \mathrm{~N}$ ammonia. The fractions which showed positive by ninhydrin reaction were combined and concentrated under reduced pressure to dryness. The powder was dissolved in $0.2 \mathrm{M}$ pyridine-acetate buffer ( $\mathrm{pH} 3.75)$ and chromatographed on a colmun of Dowex $50 \mathrm{~W}-\mathrm{X} 8(\phi=6 \mathrm{~cm}, 2200 \mathrm{ml})$ which had been previously treated with the same buffer. The eluate was collected in $20-\mathrm{ml}$ fractions. The fractions from 47 to 77 contained $580.5 \mathrm{mg}$ of II, and the fractions from 95 to 209 contained $6.50 \mathrm{~g}$ of III ( $65 \%$ yield). A yield of $1.85 \mathrm{~g}$ of IV (18.5\%) was obtained from 267 to 291 using the buffer of pH 4.5 .

III: $m p 205 \sim 210^{\circ} \mathrm{C}$ (dec.); $[\alpha]_{\mathrm{D}}^{22}-30^{\circ}$ (c 1, $\left.0.1 \mathrm{~N} \mathrm{HCl}\right) ;$ pKá $<2,2.9,7.5,9.3$; uv, end absorption; ir ( $\mathrm{KBr}$ disk); $1742 \mathrm{~cm}^{-1}$ (ester). Anal. calcd. for $\mathrm{C}_{17} \mathrm{H}_{22} \mathrm{~N}_{2} \mathrm{O}_{8} \cdot \mathrm{H}_{2} \mathrm{O}$ : C 
C 50.99, H 6.04, N 7.00, O 35.97, (M.W. 400.38). Found: C 50.78, H 6.04, N 7.17, O 35.36, M.W. 404 (titration).

IV : $\operatorname{mp~} 230 \sim 237^{\circ} \mathrm{C}$ (dec.); $[\alpha]_{\mathrm{D}}^{22}-50^{\circ}$ (c $\left.1,0.1 \mathrm{~N} \mathrm{HCl}\right) ;$ pKá $<2,3.4,7.7,9.6$; uv, end absorption; nmr, Table 1. Anal. calcd. for $\mathrm{C}_{14} \mathrm{H}_{18} \mathrm{~N}_{2} \mathrm{O}_{6} \cdot \mathrm{H}_{2} \mathrm{O}: \mathrm{C} 51.21, \mathrm{H} 6.14, \mathrm{~N} 8.53$, O 34.11, (M.W. 328.32). Found: C 50.27, H 6.16, N 8.46, O 34.02, M.W. 323 (titration).

Tetrahydro-IV (IX)

A sample (176 mg) of IV was dissolved in $30 \mathrm{ml}$ of $1 \mathrm{~N} \mathrm{HCl}$ solution, and was hydrogenated over $50 \mathrm{mg}$ of ADAms platinum oxide under atmospheric pressure at room temperature for about 5 hours. Two moles of hydrogen were absorbed. After removal of the catalyst, the solution was concentrated under reduced pressure to yield $192 \mathrm{mg}$ of hydrochloride of IX. The hydrochloride was dissolved in $3 \mathrm{ml}$ of water, and subjected to a column of Dowex $50 \mathrm{~W}-\mathrm{X} 8$ (H type, $\phi=1.0 \mathrm{~cm}, 6 \mathrm{ml}$ ). After washing with water, IX was eluted with $0.5 \mathrm{~N}$ ammonia and was dried under reduced pressure. Crystallization with water-ethanol yielded $164 \mathrm{mg}$ of colorless needles $\left(95 \%\right.$ yield); $\mathrm{mp} 260^{\circ} \mathrm{C}$ (dec.). Anal. calcd. for $\mathrm{C}_{14} \mathrm{H}_{22} \mathrm{~N}_{2} \mathrm{O}_{6} \cdot \mathrm{H}_{2} \mathrm{O}:$ C 50.59, $\mathrm{H}$ 7.28, N 8.43, O 33.70, (M.W. 332.35). Found: C 50.08, H 7.48, N 8.40, O 33.40.

$\mathrm{D}$-Lactic acid ammonium salt

A $3 \mathrm{~g}$ quantity of III was dissolved in $100 \mathrm{ml}$ of $2 \mathrm{~N} \mathrm{NaOH}$, and was hydrolyzed at $60^{\circ} \mathrm{C}$ for 18 hours. The reaction mixture was passed through a column of Dowex $50 \mathrm{~W}-\mathrm{X} 8(\mathrm{H}$ type, $\phi=2.5 \mathrm{~cm}, 150 \mathrm{ml}$ ). The effluent was neutralized with $0.5 \mathrm{~N}$ ammonia and evaporated under reduced pressure to dryness. The residue was identified with ammonium lactate by comparison with an authentic sample; $722 \mathrm{mg}$ (yield $94.5 \%),[\alpha]_{\mathrm{D}}^{22}-2.8^{\circ}$ (c 5, water), ir (liquid film), 1725 (sh.), 1670, 1580, 1450, 1415, 1318, 1123, 1083, 1040, 922, 851, $775 \mathrm{~cm}^{-1}$.

Tetraacetyl-dimethyl ester of IV (VIII)

A $300 \mathrm{mg}$ of IV was dissolved in $10 \mathrm{ml}$ of methanol containing $10 \% \mathrm{HCl}$, and was refluxed for 3 days. The reaction mixture was evaporated under reduced pressure to yield $210 \mathrm{mg}$ of a pale yellow syrup. A $130 \mathrm{mg}$ quantity of the syrup was dissolved in $5 \mathrm{ml}$ of pyridine, and $2.5 \mathrm{ml}$ acetic anhydride was added dropwise. The reaction mixture was kept overnight at room temperature and was evaporated under reduced pressure to dryness. The residue was dissolved in $5 \mathrm{ml}$ of chloroform and the solution was passed through a column of silica gel (Mallinckrodt, $\phi=1.0 \mathrm{~cm}, 5 \mathrm{~g}$ ). After washing with chloroform (ca. $50 \mathrm{ml}$ ), the column was developed with chloroform-methanol (100:40 in volume). The fractions which gave one spot on thin-layer chromatography were collected, and concentrated under reduced pressure to yield $30 \mathrm{mg}$ of a pale yellow powder; $\mathrm{mp} 156^{\circ} \mathrm{C}(\mathrm{dec}$ ), $\mathrm{nmr}(\delta)$; $1.90,1.98,2.05,2.12$ (3H singlets $\times 4$, tetraacetyl), 3.71, $3.80(3 \mathrm{H}$ singlets $\times 2$, dimethyl ester). MS; $\mathrm{M}^{+}$m/e 506.

Hydrated product of IV (V)

A $3 \mathrm{~g}$ of III was dissolved in $100 \mathrm{ml}$ of $12 \mathrm{~N} \mathrm{HCl}$ and was refluxed for 18 hours. The reaction mixture was evaporated under reduced pressure to dryness. The material was dissolved in $0.2 \mathrm{M}$ pyridine - acetat buffer ( $\mathrm{pH} 3.75$ ), and chromatographed on a column of Dowex $50 \mathrm{~W}-\mathrm{X} 8$ which was previously treated with the same buffer $(\phi=4.0 \mathrm{~cm}, 500 \mathrm{ml})$. The column was eluted with the same buffer. The eluate was collected in $20-\mathrm{ml}$ fractions. The fractions from 33 to 99 contained $900 \mathrm{mg}$ of III. The pH of the buffer was raised to 4.5 from fraction No. 151 . The eluate from 167 to 291 contained $1.89 \mathrm{~g}$ of the mixture of the hydrated products of III and IV. Finally $432 \mathrm{mg}$ of V (14.4\% yield) was obtained from the eluate from 333 to 368 by using $0.4 \mathrm{M}$ buffer of $\mathrm{pH} 4.75 . \mathrm{mp}>260^{\circ} \mathrm{C}$, uv ; end absorption, nmr; Table 2. Anal. calcd. for $\mathrm{C}_{14} \mathrm{H}_{20} \mathrm{~N}_{2} \mathrm{O}_{7} \cdot \mathrm{H}_{2} \mathrm{O}: \mathrm{C}$ 48.55, $\mathrm{H}$ 6.40, N 8.09, O 36.96, (M.W. 346.33). Found: C 48.23, H 6.26, N 8.00, O 36.45.

Tetrahydro I (VII)

A $1.00 \mathrm{~g}$ of I was dissolved in $200 \mathrm{ml}$ of water and hydrogenated over $100 \mathrm{mg}$ of ADAMs platinum oxide under atmospheric pressure at room temperature for about 3 hours. Two moles of hydrogen was absorbed. After removal of the catalyst, the solution was 
evaporated under reduced pressure to dryness. Crystallization from water-ethanol yielded $835 \mathrm{mg}$ of colorless needles $\left(83.5 \%\right.$ yield). $\mathrm{mp} 213 \sim 215^{\circ} \mathrm{C}$ (dec.), ir (KBr disk); $1724 \mathrm{~cm}^{-1}$ (ester). Anal. calcd. for $\mathrm{C}_{10} \mathrm{H}_{17} \mathrm{NO}_{5}$ : C 51.94, H 7.41, $\mathrm{N} \mathrm{6.06,} \mathrm{O} \mathrm{34.60,} \mathrm{(M.W.} \mathrm{231.24).}$ Found: C 51.86, H 7.43, N 5.99, O 34.72, M.W., 231 (MS $\mathrm{M}^{+} \mathrm{m} / \mathrm{e}$ ).

(+)-6-Amino-trans-5-hydroxy-1,3-cyclohexadiene-1-carboxylic acid (VI)

A $1.00 \mathrm{~g}$ quantity of I was dissolved in $200 \mathrm{ml}$ of $2 \mathrm{~N} \mathrm{NaOH}$ solution, and hydrolyzed at $60^{\circ} \mathrm{C}$ for 5 hours. After cooling, the reaction mixture was added to a column of Dowex $50 \mathrm{~W}-\mathrm{X} 8$ ( $\mathrm{H}$ type, $\phi=2.5 \mathrm{~cm}, 50 \mathrm{ml}$ ). After washing with water, the column was eluted with $0.5 \mathrm{~N}$ ammonia. The fractions containing IV and VI were combined and evaporated under reduced pressure to dryness. The material was chromatographed on a cellulose column (Whatmann CF $11, \phi=2.5 \mathrm{~cm}, 50 \mathrm{~g}$ ) with $n$-butanol - acetic acid-water $(3: 1: 1$ in volume). The eluate was collected in $15-\mathrm{ml}$ fractions. The fractions from 86 to 156 contained $680 \mathrm{mg}$ of VI ( $68.0 \%$ yield) and the fractions from 186 to 235 contained $130 \mathrm{mg}$ of IV $\left(13.0 \%\right.$ yield). $\mathrm{mp} 192^{\circ} \mathrm{C},[\alpha]_{\mathrm{D}}^{22}+446^{\circ}(c 1$, water $), \lambda_{\operatorname{msx}}(\varepsilon) ; 272 \mathrm{~nm}(5425)$. Anal. calcd. for $\mathrm{C}_{7} \mathrm{H}_{9} \mathrm{NO}_{3}$ : C 54.19, H 5.85, N 9.03, O 30.94, (M.W. 151.15). Found: C 54.23, H 5.85 , N 9.00 , O 30.88 .

\section{References}

1) Hashimoto, T.; S. Kondo, T. Takita, M. Hamada, T. Takeuchi, Y. Okami \& H. Umezawa : Oryzoxymycin, a new antibiotic.: J. Antibiotics $21: 653 \sim 658,1968$

2) McCormick, J.R.D.; J. Reichenthal, U. Hirsh \& N. O. Sjolander : Biosynthesis of the tetracyclines. III. A new amino acid from $S$. aureofaciens; $(+)$-trans-2,3-dihydro-3-hydroxyanthranilic acid. J. Amer. Chem. Soc. $84: 3711 \sim 3714,1962$ 